\title{
Early-life obesity and adulthood colorectal cancer risk: a meta-analysis
}

\author{
Harrison Garcia ${ }^{1}$ and Mingyang Song ${ }^{2}$
}

Suggested citation Garcia H, Song M. Early-life obesity and adulthood colorectal cancer risk: a meta-analysis. Rev Panam Salud Publica. 2019;43:e3. https:/ / doi.org/10.26633/RPSP.2019.3

ABSTRACT Objective. This meta-analysis examines the relationship between early-life obesity and risk of colorectal cancer (CRC) in adulthood.

Methods. Asystematic search of Google Scholar, PubMed, and reference data was conducted. Fifteen relevant studies were identified and meta-analyzed, for men and women separately. A random-effects model was used to compare the multivariable-adjusted relative risks (RR) of overall and subsite-specific CRC to the highest versus lowest categories of body mass index (BMI) in early life. Meta-regression was performed on factors that may have contributed to between-study heterogeneity.

Results. High early-life BMI was associated with a 39\% increased risk of CRC in adult men $(R R=1.39,95 \% C I=1.20-1.62, P<0.0001)$ and a $19 \%$ increased risk of $C R C$ in adult women $(R R=1.19,95 \% C I=1.06-1.35, P=0.004)$. No statistically significant heterogeneity was identified in meta-regression according to tumor subsite $(R R=1.06,95 \% C I=0.97-1.17$, $R R=1.08,95 \% C I=0.99-1.18$ for male and female proximal colon cancer; $R R=1.51$, $95 \% C I=1.22-1.87, R R=1.08,95 \% C I=0.98-1.19$ for male and female distal colon cancer; and $R R=1.39,95 \% C I=1.1-1.77, R R=1.51,95 \% C I=0.94-2.03$ for male and female rectal cancer) or other factors, including age of BMI assessment, self-reported or measured BMI, and adjustment for smoking.

Conclusions. The results suggest that high early-life BMI is associated with increased risk of CRC in adulthood. Further studies should investigate adult CRC risk in early-life obese individuals from non-Western countries and the underlying mechanisms by which early-life adiposity may influence CRC pathogenesis.

Keywords Colorectal neoplasms; rectal neoplasms; obesity; body mass index; meta-analysis.

Colorectal cancer (CRC) causes the mortality of more than 50000 people per year in the United States, with CRC risk in the Americas having increased

Clarkstown High School North, New City, New York, United States of America. Send correspondence to Harrison Garcia, harrysong22@gmail.com

2 Departments of Epidemiology and Nutrition, Harvard T.H. Chan School of Public Health, Boston, Massachusetts, United States. throughout the past decade (1). Numerous studies have identified that a high adult body mass index (BMI) is associated with an increased risk of CRC in adulthood, referring to inflammatory cytokines, metabolic syndrome, and diet as potential causes of CRC pathogenesis $(2-6)$. However, given the long induction period of carcinogenesis in the colon and rectum, early-life obesity has also been suggested to affect CRC development later in life (7).
Various narrative and systematic reviews have described the impact of early-life obesity on general causes of morbidity and mortality in adulthood, but none thoroughly addressed increased risks of CRC, only providing narrative review on studies concerning the risk of CRC mortality $(8,9)$. The small sample sizes of individual studies that investigated the relationship between high early-life BMI and adult CRC risk 
also produced underpowered results for subsite-specific CRC risk. This poses the following question: is obesity in early life associated with an increased risk of CRC in adulthood?

Tumor sublocation groups and effect sizes vary from studies that assessed the risk of CRC risk during adulthood in individuals obese in early-life, prompting the need for a meta-analysis. Although one meta-analysis has investigated the association between early-life obesity and CRC risk in adulthood, the authors did not conduct analyses on obese versus normal BMI categories and on tumor sublocations, leaving these associations unknown (10). This paper outlines the results of a meta-analysis that elucidates the relationship between obese early-life BMI and CRC risk in adulthood.

\section{MATERIALS AND METHODS}

\section{Study selection}

This meta-analysis was conducted in coherence with guidelines enumerated by the Meta-analysis of Observational Studies in Epidemiology checklist (11). Google Scholar (Google Inc., Mountain View, California, United States) and PubMed Central (U.S. National Library of Medicine, Bethesda, Maryland, United States) were used to search for studies published before 20 August 2017 using the following keywords: body mass index OR BMI OR overweight $\mathrm{OR}$ obese AND childhood OR adolescence OR youth AND risk OR morbidity OR mortality AND men OR males OR middle age AND cancer OR colorectal OR colorectal cancer OR colon. The option to use MeSH terms was also applied in PubMed and all languages were included in the language filter to adequately search for non-English studies. The titles and abstracts that did not mention the previous search terms were excluded. The references of included studies were assessed to identify more relevant literature. Any remaining study was included if it (a) had reported effect size in terms of relative risk (RR), odds ratio (OR), or hazard ratio (HR); (b) had a prospective cohort design; and (c) had only assessed BMI for participants 25 years of age or younger. Restrictions on publication date and language were not used.

\section{Data extraction and analysis}

Data from the following categories were extracted from the included studies: study name, year of publication, author, number of male and female participants, number of male and female cancer cases, age at BMI assessment, age at baseline, BMI comparison groups, methods of BMI collection (recall vs. measurements), effect sizes with 95\% confidence intervals $(95 \% \mathrm{CI})$, and adjusting confounding factors. All studies investigated the relationship between BMI (kilograms per meters squared) recorded or recalled before age 25 and risk of CRC above age 34 . Variance between BMI comparison groups was concluded to be negligible. An analysis was conducted comparing overweight/obese and normal groups as all studies estimated risks by comparing CRC incidence in an obese group to that of a normal group. OR and HR were interpreted as RR in the final analysis.

Both contributors to this meta-analysis (HG and MS) individually searched for literature and identified extractable data while discussing study inclusion via voice calls and email. Study quality was determined using the 9-star $\mathrm{New}^{-}$ castle-Ottawa scale (12); scores per study are reported in Table 1. For studies that examined both cancer incidence and mortality, only the CRC incidence data were extracted. Growth charts provided by the United States Centers for Disease Control and Prevention (CDC) were used to derive the BMI comparison groups for studies that conducted analyses based on United States BMI percentiles (13).

Heterogeneity was assumed to be present as studies all analyzed different populations. The $\mathrm{I}^{2}$ statistic also demonstrated moderate heterogeneity in men at $53.2 \%$ and low heterogeneity in women at $24.6 \%$ ( $<25 \%$ low heterogeneity, $25-$ $75 \%$ moderate heterogeneity, > 75\% severe heterogeneity); therefore, a random effects model was used for data analysis. Evidence of publication bias was not identified after testing studies with Egger's regression intercept, Rosenthal's fail-safe n, and Begg's rank correlation. Men and women were analyzed separately because of the well established sex difference in the relationship between BMI and CRC $(14,15)$. Microsoft Excel ${ }^{\mathrm{TM}}$ (Microsoft Corp., Redmond, Washington, United States) and Comprehensive Meta-Analysis version 3 (Biostat, Englewood, New Jersey, United
States) software programs were used to compile data and analyze statistical relationships (16). Confidence intervals were set at $95 \%$ and two-tailed $P$-values are presented in the results.

\section{RESULTS}

Following literature review, 15 studies (17 - 31) comprising more than 4.7 MM participants (around 3.2 MM men and 1.5 MM women) with 15288 CRC cases were included in this meta-analysis (Figure 1, Table 1). The final analysis demonstrated a 39\% increase in adulthood CRC risk for obese males in early-life $(\mathrm{RR}=1.39 ; 95 \% \mathrm{CI}=1.20-1.62, P<$ 0.0001 ) and a $19 \%$ increase in adulthood CRC risk for obese females in early-life $(\mathrm{RR}=1.19 ; 95 \% \mathrm{CI}=1.06-1.35 ; P=0.004)$ when compared to controls (Table 2). Analysis of tumor sublocation (Table 3) also revealed that in men, an obese earlylife BMI was more strongly associated with distal colon cancer $(\mathrm{RR}=1.51$; $95 \% \mathrm{CI}=1.22-1.87, P<0.0001)$ and rectal cancer $(\mathrm{RR}=1.39 ; 95 \% \mathrm{CI}=1.10-1.77 ; P<$ $0.0001)$ than proximal colon cancer $(\mathrm{RR}=$ $1.06 ; 95 \% \mathrm{CI}=0.97-1.17 ; P<0.0001)$, whereas in women the association was stronger for rectal cancer $(\mathrm{RR}=1.38$; $95 \% \mathrm{CI}=0.94-2.03 ; P=0.009)$ than proximal $(\mathrm{RR}=1.08 ; 95 \% \mathrm{CI}=0.99-1.18, \mathrm{P}=$ $0.009)$ and distal colon cancer $(R R=1.08$; $95 \% \mathrm{CI}=0.98-1.19 ; P=0.009)(P$ for heterogeneity $=0.22$ and 0.22 , respectively). Sensitivity analyses exhibited a relative risk range of $1.33-1.43$ for males and $1.12-1.23$ for females. Meta-regression was performed on all potential modifiers (Table 3).

\section{DISCUSSION}

Currently, this is the only metaanalysis investigating the association between early-life obesity and adulthood CRC incidence by comparing distinct groups of obese and non-obese individuals. This meta-analysis identified pooled, multivariable-adjusted relative risks of CRC and its subsites in men and women by comparing high versus low BMI categories in early-life, which were not identified by a previously published meta-analysis (10). Although all results regarding risk of CRC contain significant $P$-values, the confidence intervals for proximal colon cancer in men and all tumor sublocations in women include RRs at or 


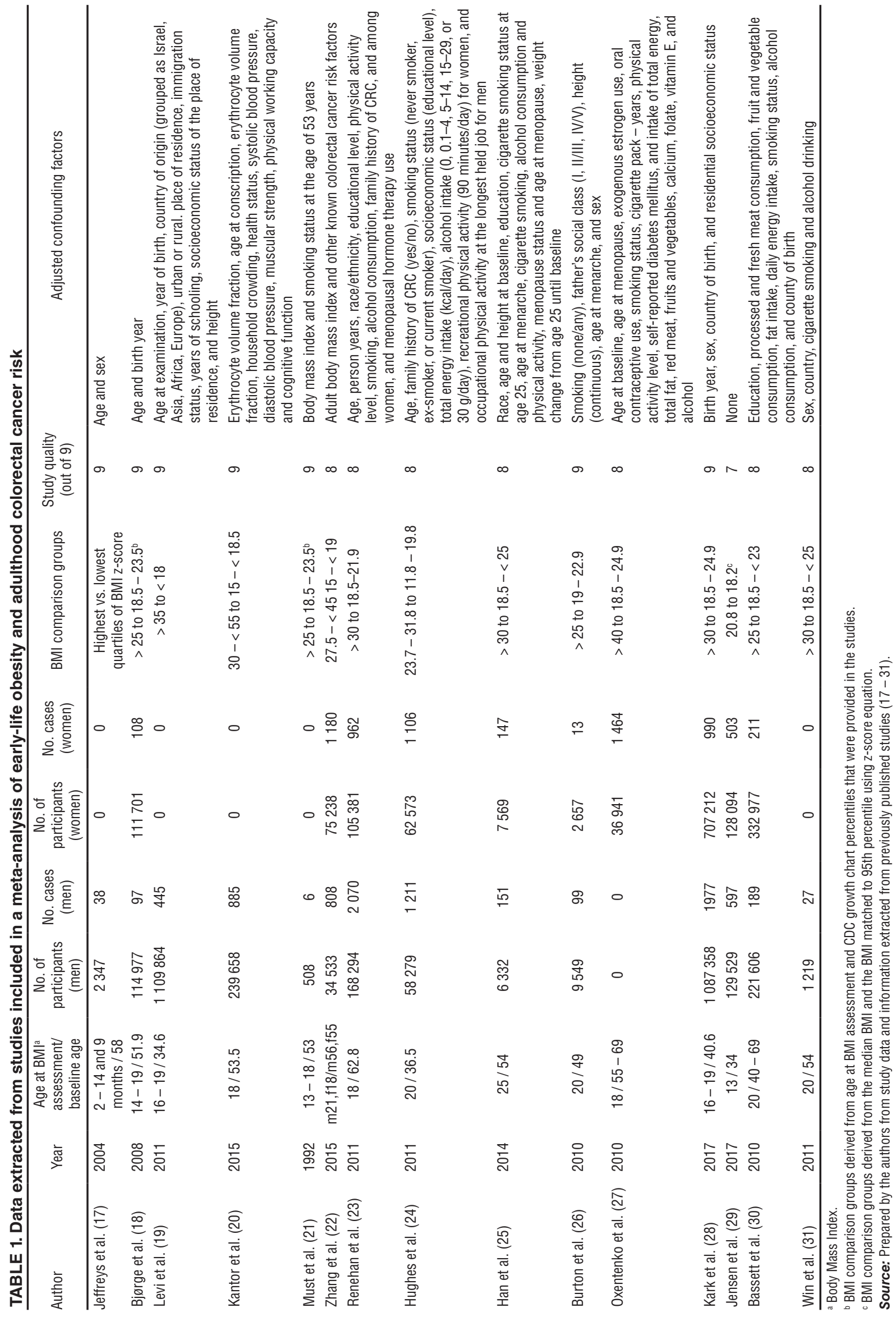


FIGURE 1. Section process for a meta-analyisis of studies on early-life obesity and adulthood colorectal cancer risk

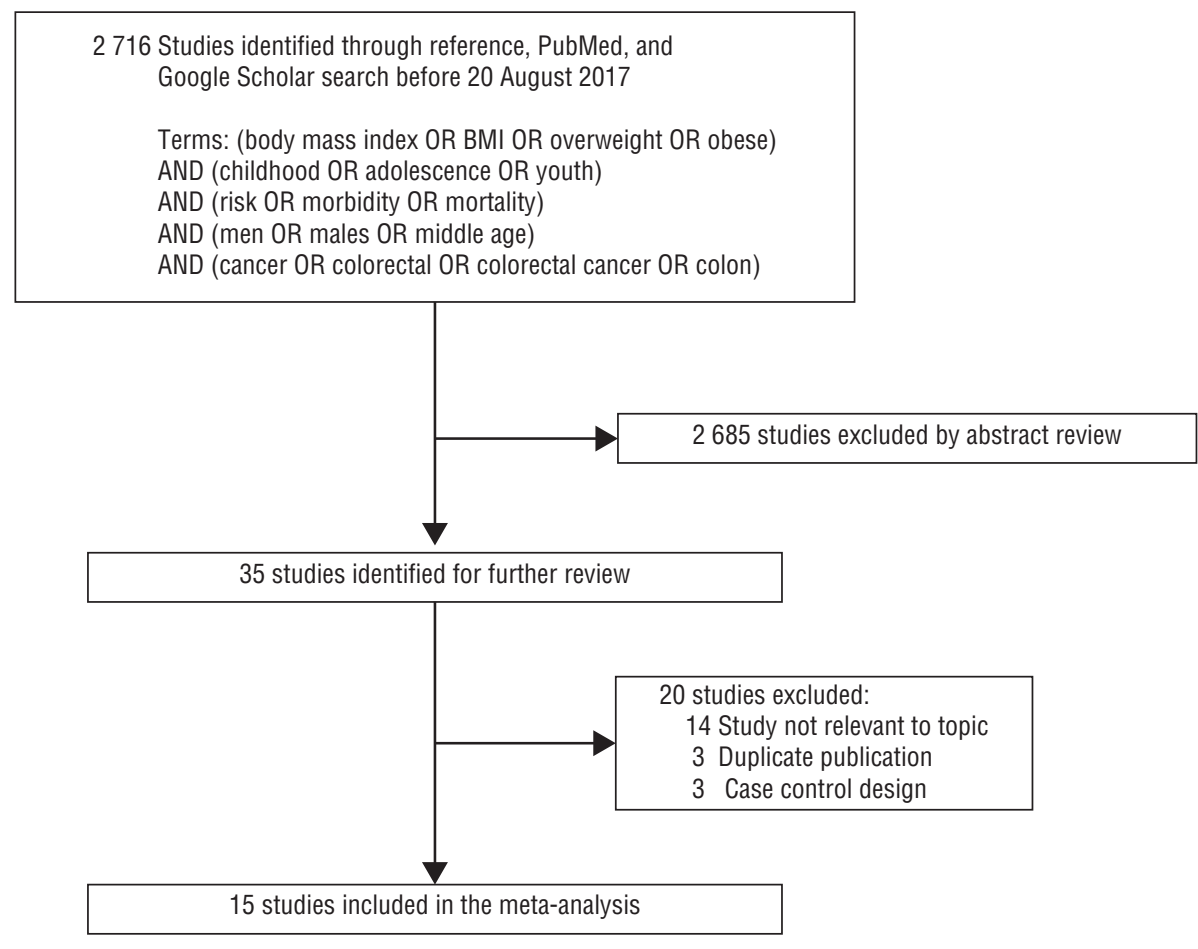

Source: Prepared by the authors from study data.

below 1 . Therefore, such results should be interpreted cautiously: despite the significant $P$-values created by the large total population included in the final analysis, the confidence interval suggests that there may not be increased risk for the aforementioned cancer sublocations in men and women.
Meta-regression also revealed that there were no significant differences between the ages at which participants were assessed for early-life BMI, the methods of early-life BMI assessment, and adjustment for smoking, demonstrating that none of these factors modifies the results of this meta-analysis (Table 3 ).
All studies included were conducted robustly according to the assessment using the 9-star Newcastle-Ottawa scale, suggesting that the quality of the individual studies should not confound the results of this review (12). Although around half of the studies did not attain perfect scores due to their methods of recalling early-life BMI, meta-regression demonstrated that there was no significant difference in CRC risk between studies that used recall methods and those that used pre-recorded data $(P=$ 0.49 and 0.84 for men and women, respectively).

Increased risks for distal cancer and rectal cancer among obese individuals can be attributed to increased rates of such cancers among all individuals less than 55 years of age (32). Possibilities for the source of increased risk of CRC in obese individuals include insulin resistance and inflammatory cytokines $(33$ - 38). Obesity has been associated with hyperinsulinemia, an oversupply of insulin circulating in blood caused by insulin resistance (33, 34). It has been suggested that hyperinsulinemia is associated with decreased production of proteins that inhibit insulin-like growth factor-1 (IGF1), a protein that may induce carcinogenesis $(33,34)$. Analysis of CRC tumors has shown increased IGF1 expression in metastasized cells (34). Hyperinsuline$\mathrm{mia}$ is also related to diseases such as type II diabetes and metabolic syndrome, both of which are associated

TABLE 2. Relative risks (RR) of late life colorectal cancer (CRC) in early-life obese males and females

\begin{tabular}{|c|c|c|c|c|c|c|c|}
\hline Authors of male studies & $\begin{array}{c}\text { Study RR (95\% } \\
\text { Confidence Interval) }\end{array}$ & Study weight ${ }^{\mathrm{a}}$ & $P$-value & Authors of female studies & $\begin{array}{c}\text { Study RR } \\
(95 \% \text { Confidence Interval) }\end{array}$ & $\begin{array}{l}\text { Study } \\
\text { weight }^{\mathrm{a}}\end{array}$ & $P$-value \\
\hline Jeffreys et al. (17) & $1.36(0.57-3.24)$ & 2.62 & 0.49 & Bjørge et al. (18) & $2.00(1.20-3.50)$ & 4.64 & 0.73 \\
\hline Bjørge et al. (18) & $2.10(1.10-4.10)$ & 4.11 & 0.03 & Zhang et al. (22) & $1.44(1.06-1.95)$ & 12.43 & 0.02 \\
\hline Levi et al. (19) & $1.53(1.17-2.00)$ & 11.34 & $<0.01$ & Renehan et al. (23) & $1.44(0.89-2.34)$ & 5.60 & 0.14 \\
\hline Kantor et al. (20) & $2.55(1.44-4.61)$ & 4.93 & $<0.01$ & Hughes et al. (24) & $1.12(0.87-1.43)$ & 17.02 & 0.37 \\
\hline Must et al. (21) & $9.10(1.08-76.38)$ & 0.50 & 0.04 & Han et al. (25) & $1.10(0.44-2.78)$ & 1.64 & 0.84 \\
\hline Zhang et al. (22) & $1.18(0.84-1.65)$ & 9.41 & 0.34 & Burton et al. (26) & $1.23(0.15-10.07)$ & 0.32 & 0.85 \\
\hline Renehan et al. (23) & $1.48(1.08-2.03)$ & 9.99 & 0.02 & Oxentenko et al. (27) & $0.46(0.07-3.23)$ & 0.39 & 0.42 \\
\hline Hughes et al. (24) & $1.21(0.93-1.56)$ & 11.62 & 0.15 & Kark et al. (28) & $1.52(0.90-2.59)$ & 4.75 & 0.12 \\
\hline Han et al. (25) & $1.65(0.87-3.11)$ & 4.31 & 0.12 & Jensen et al. 29) & $1.08(0.98-1.19)$ & 44.85 & 0.12 \\
\hline Burton et al. (26) & $1.25(0.60-2.61)$ & 3.45 & 0.56 & Bassett et al. (30) & $1.07(0.73-1.58)$ & 8.36 & 0.73 \\
\hline Kark et al. (28) & $1.52(1.13-2.04)$ & 10.55 & 0.01 & Overall RR & $1.19(1.06-1.35)$ & 100 & 0.004 \\
\hline Jensen et al. (29) & $1.06(0.97-1.16)$ & 16.47 & 0.20 & & & & \\
\hline Bassett et al. (30) & $1.21(0.88-1.67)$ & 9.86 & 0.24 & & & & \\
\hline Win et al. (31) & $3.00(0.06-14.97)$ & 0.85 & 0.18 & & & & \\
\hline Overall RR & $1.39(1.20-1.62)$ & 100 & $<0.0001$ & & & & \\
\hline
\end{tabular}

${ }^{a}$ Adjusted study weight as a percent of 100 .

Source: Prepared by the authors from study data. 
TABLE 3. Meta-regression analysis on potentially confounding factors in included studies on early-life obesity and adulthood colorectal cancer risk

\begin{tabular}{|c|c|c|c|c|c|c|c|c|c|}
\hline \multirow[b]{2}{*}{ Modifier } & \multirow[b]{2}{*}{ Subgroup } & \multicolumn{4}{|c|}{ Men } & \multicolumn{4}{|c|}{ Women } \\
\hline & & $\begin{array}{c}\text { No. of } \\
\text { participants }\end{array}$ & Relative risks & $\begin{array}{l}\text { No. of } \\
\text { studies }\end{array}$ & $P$ value & $\begin{array}{c}\text { No. of } \\
\text { participants }\end{array}$ & Relative risks & $\begin{array}{l}\text { No. of } \\
\text { studies }\end{array}$ & $P$ value \\
\hline \multicolumn{10}{|c|}{ Age at assessment of body mass index (BMI) } \\
\hline & Early adulthood & 229332 & $1.26(1.06-1.51)$ & 6 & $0.56^{a}$ & 442717 & $1.11(0.90-1.34)$ & 5 & $0.28^{\mathrm{a}}$ \\
\hline \multicolumn{10}{|c|}{ Methods of BMI assessment } \\
\hline & $\begin{array}{l}\text { Recalled adolescent/early } \\
\text { adulthood BMI }\end{array}$ & 490263 & $1.29(1.11-1.50)$ & 6 & \multirow[t]{2}{*}{$0.49^{\mathrm{a}}$} & 583738 & $1.22(1.04-1.44)$ & 5 & \multirow[t]{2}{*}{$0.84^{\mathrm{a}}$} \\
\hline & $\begin{array}{l}\text { BMI measured in adolescence/ } \\
\text { early adulthood }\end{array}$ & 2752661 & $1.54(1.17-2.02)$ & 8 & & 2746329 & $1.31(0.94-1.83)$ & 5 & \\
\hline \multicolumn{10}{|c|}{ Cancer location } \\
\hline & Proximal colon & 187808 & $1.06(0.97-1.17)$ & 2 & \multirow{3}{*}{$\begin{array}{l}0.22^{\mathrm{a}} \\
<0.001^{\mathrm{b}}\end{array}$} & 227608 & $1.08(0.99-1.18)$ & 3 & $0.22^{\mathrm{a}}$ \\
\hline & Distal colon & 1168143 & $1.51(1.22-1.87)$ & 2 & & 227608 & $1.08(0.98-1.19)$ & 3 & \multirow{2}{*}{$0.01^{b}$} \\
\hline & Rectum & 2263453 & $1.39(1.10-1.77)$ & 8 & & 875116 & $1.38(0.94-2.03)$ & 3 & \\
\hline \multicolumn{10}{|c|}{ Adjustment for smoking } \\
\hline
\end{tabular}

a $P$ values from meta-regression analysis.

${ }^{b} \mathrm{P}$ values from analysis of the three tumor sublocations.

Source: Prepared by the authors from study data.

with increased rates of CRC and have been increasing rapidly among obese youth (35). Early-life obesity can contribute to expression of IGF1 earlier in life than those with normal BMIs, leading to increased incidence of CRC among individuals who have been obese since childhood.

Excess adipose tissue may produce large amounts of tumor necrosis factor alpha, resistin, and interlukin-6; all of which have been found to induce inflammation and have been found in higher concentrations among individuals with CRC than in cancer free controls $(36-38)$. Thus, individuals who have been obese as youth experience inflammation earlier than their non-obese counterparts, decreasing the time required for CRC pathogenesis in obese individuals $(36-39)$. Excess adipose tissue may indicate a carcinogenic diet, as well as induce carcinogenesis itself because obese individuals typically consume large amounts of foods associated with CRC pathogenesis $(40-44)$. High consumption of processed red meat, eggs, and refined sugar has been positively associated with increased rates of CRC (45-47). Such foods are typically consumed in larger amounts by obese individuals than by those with normal BMIs. Heterocyclic amines and nitrates found in processed meats have been shown to be associated with CRC pathogenesis in numerous studies $(45,48)$. Those who have obese early-life BMIs would thus consume a larger volume of such mutagens than people with normal early-life BMIs, which would lead to increased CRC rates.

Limitations. Studies that asked participants to recall their childhood BMI at baseline could have skewed results as this design is susceptible to recall bias, but this bias has been shown to be insignificant by meta-regression. All studies included in this analysis had checked hospital, national health service, and death certificate records, and followed up with participants to identify those who developed CRC in adulthood; therefore, the standardized methods of cancer screening programs in all studies should not have skewed the overall results.

Caution should be used when interpreting the outcomes of this analysis as diet may confound the association between the physical presence of excess adipose tissue and increased CRC rates. The participants in all studies resided in developed, Western countries, where diets differ significantly from those of other regions. Some studies also did not adjust for dietary factors, such as consumption of processed red meat and refined carbohydrates.
The authors believe the search strategy for English and non-English articles was adequate as all languages available in the filter section of PubMed and Google Scholar were included. However, since all the studies found through the search were in English, there may be other non-English publications analyzing non-Western populations that were not included in this review; therefore, the results of this analysis should only be applied to those living in Western countries.

\section{Conclusions}

A strong relationship exists between high early-life BMI and increased CRC incidence in adulthood. Similar relationships have also been identified between high early-life BMI and increased risk of distal and rectal cancer in men, and rectal cancer in women. Future research should adjust for diet and analyze non-Western populations to better and more comprehensively characterize the impacts of early-life adiposity on CRC risk in adulthood. The cellular and molecular mechanisms of CRC pathogenesis should also be identified to better understand how an accumulation of excess adipose tissue throughout life contributes to carcinogenesis. 
Future studies should analyze other populations, identify the mechanisms of how adipose tissue induces carcinogenesis, and adjust for diet in order to limit factors that may confound the Group. United States cancer statistics: 1999 - 2014 incidence and mortality webbased report. Atlanta: U.S. Department of Health and Human Services, Centers for Disease Control and Prevention, National Cancer Institute; 2017. Available from: https://wonder.cdc.gov/cancer.html Accessed 28 September 2017.

2. Larsson SC, Wolk A. Obesity and colon and rectal cancer risk: a meta-analysis of prospective studies. Am J Clin Nutri. 2002; 86(3):556-65. doi:10.1093/ajcn/86.3.556

3. Billy M, Sholihah $H$, Andanni K, Anggraeni MI, Siregar SM, Mirtha LT. Obesity as predictor of mortality of colorectal cancer: an evidence-based case report. Acta Med Indones. 2016;48(3):242-6.

4. Jarvis D, Mitchell JS, Law PJ, Palin K, Tuupanen S, Gylfe A, et al. Mendelian randomisation analysis strongly implicates adiposity with risk of developing colorectal cancer. Br J Cancer. 2016;115(2):266-72. doi:10.1038/bjc. 2016.188

5. Park SM, Yun YH, Kim YA, Jo M, Won YJ, Back JH, Lee, ES. Pre-diagnosis of body mass index and risk of secondary primary cancer in male cancer survivors: a large cohort study. J Clin Oncol. 2016; 34(34): 1-10. doi:10.1200/JCO.2016.66.4920

6. Thrift AP, Gong J, Peters U, Chang-Claude J, Rudolph A, Slattery ML, et al. Mendelian randomization study of body mass index and colorectal cancer risk. Cancer Epidemiol Biomarkers Prev. 2015;24(7): 1024-31. doi:10.1158/1055-9965.EPI-14-1309

7. Wei EK, Wolin KY, Colditz GA. Time course of risk factors in cancer etiology and progression. J Clin Oncol. 2010;28(26): 4052-7. doi:10.1200/JCO.2009.26.9324

8. Dietz WH. Childhood weight affects adult morbidity and mortality. J Nutri. 1998; 128(2): 411-14. doi:10.1093/jn/128.2.411S

9. Park MH, Falconer C, Viner RM, Kinra S. The impact of childhood obesity on morbidity and mortality in adulthood: A systematic review. Obes Rev. 2012;13(11):985-1000. doi:10.1111/j.1467-789X.2012.01015.x

10. Hidayat K, Yang CM, Shi BM. Body fatness at an early age and risk of colorectal cancer. Int J Cancer. 2017;142(4):729-40. doi: 10.1002/ijc.31100

11. Stroup DF, Berlin JA, Morton SC, Olkin I, Williamson GD, Rennie D, et al. Metaanalysis of observational studies in epidemiology: a proposal for reporting. Meta-analysis Of Observational Studies in Epidemiology (MOOSE) group. JAMA. 2000; 283(15):2008-12. doi:10.1001/jama. 283.15.2008

12. Wells GA, Shea B, Peterson J, Welch V, Losos M, Tugwell P. The Newcastle-

relationship between excess adipose tissue in early-life and CRC risk in adulthood.

Conflict of interests: None declared.

\section{REFERENCES}

Ottawa Scale (NOS) for assessing the quality of nonrandomised studies in meta-analyses. Ottawa: Ottawa Hospital Research Institute; 2000.

13. United States Centers for Disease Control and Prevention, National Center for Health Statistics. CDC growth charts: United States; 2000 May 30. Available from: https:/ / www.cdc.gov/growthchart/ Accessed 28 September 2017.

14. Koo JH, Leong RWL. Sex differences in epidemiological, clinical and pathological characteristics of colorectal cancer. J Gastroenterol Hepatol. 2010;25(1):33-42. doi:10.1111/j.1440-1746.2009.05992.x

15. Majek O, Gondos A, Jansen L, Emrich K, Holleczek B, Katalinic A, et al. Sex Differences in colorectal cancer survival: population-based analysis of 164,996 colorectal cancer patients in Germany. PLoS ONE. 2013;8(7). doi:10.1371/journal. pone.0068077

16. Borenstein M, Hedges L, Higgins J, Rothstein H. Comprehensive meta-analysis Version 3. Biostat; 2017. Available from: https: / / www.meta-analysis.com Accessed 13 March 2017.

17. Jeffreys M, Smith G. Childhood body mass index and later cancer risk: a 50-year follow-up of the Boyd Orr study. Int J Cancer. 2004;112;348-51.

18. Bjørge T, Engeland A, Tverdal A, Smith GD. Body mass index in adolescence in relation to cause-specific mortality: a follow-up of 230,000 Norwegian adolescents. Am J Epidemiol. 2008;168:30-7. doi: 10.1093/aje/kwn096

19. Levi Z, Kark JD, Barchana M, Liphshitz I, Zavdi O, Tzur D, Derazne E. Measured body mass index in adolescence and the incidence of colorectal cancer in a cohort of 1.1 million males. Cancer Epidemiol Biomarkers Prev. 2011;20(12):2524-31.

20. Kantor EB, Udumyan R, Signorello LB, Giovannucci EL, Montgomery S, Fall K. Adolescent body mass index and erythrocyte sedimentation rate in relation to colorectal cancer risk. Gut. 2015;1-7. doi: 10.1136/gutjnl-2014-309007

21. Must A, Jaques PF, Dallal GE, Bajema CJ, Dietz WH. Long-term morbidity and mortality of overweight adolescents. New Engl J Med. 1992; 327(19):1350-5. doi: 10.1056/NEJM199211053271904

22. Zhang X, Wu K, Giovannucci EL, Ma J, Colditz GA, Fuchs CS, Willett WC. Early life body fatness and risk of colorectal cancer in U.S. women and men-results from two large cohort studies. Cancer Epidemiol Biomarkers Prev. 2015; 24(4):690-7. doi:10.1158/1055-9965.EPI-140909-T
Disclaimer. Authors hold sole responsibility for the views expressed in the manuscript, which may not necessarily reflect the opinion or policy of the RPSP/ PAJPH and/or PAHO.
23. Renehan AG, Flood A, Adams KF, Olden M, Hollenbeck AR, Cross AJ, Leitzmann MA. Body mass index at different adult ages, weight change, and colorectal cancer risk in the National Institutes of Health-AARP Cohort. Am J Epidemiol. 2011;176(12): 1130-40. doi:10.1093/aje/ kws192

24. Hughes LA, Simons CC, Van Den Brandt PA, Goldbohm A, Engeland M, Weijenberg MP. Body size and colorectal cancer risk after 16.3 years of follow-up: an analysis from the Netherlands Cohort Study. Am J Epidemiol. 2011;174(10):1127-39. doi:10. 1093/aje/kwr247

25. Han X, Stevens J, Truesdale KP, Bradshaw PT, Newton AK, Prizment AE, Platz EA. Body mass index at early adulthood, subsequent weight change and cancer incidence and mortality. Int J Cancer. 2014;135(12):2900-9. doi:10.1002/ijc.28930

26. Burton A, Martin R, Galobardes B, Smith GD, Jeffreys M. Young adulthood body mass index and risk of cancer in later adulthood: historical cohort study. Cancer Causes Control. 2010;21:2069-75. doi:10.1007/s10552-010-9625-3

27. Oxentenko AS, Bardia A, Vierkant RA, Wang AH, Anderson KE, Campbell PT, Sellers TA. Body size and incident colorectal cancer: a prospective study of older women. Cancer Prev Res. 2010;3:1608-20. doi:10.1158/1940-6207.CAPR-10-0116

28. Kark JD, Levi Z, Katz LH, Twig G, Derazne E, Tzur D, Weissman YL. Adolescent body mass index and risk of colon and rectal cancer in a cohort of 1.79 million Israeli men and women: a population-based study. Cancer. 2017;123:4022-30. doi:10. 1002 /cncr.30819

29. Jensen BW, Gamborg M, Gögenur I, Renehan AR, Sørensen TI, Baker JL. Childhood body mass index and height in relation to site-specific risks of colorectal cancers in adult life. Eur J Epidemiol. 2017; 32:1-10. doi: 10.1007/s10654-017-0289-0

30. Bassett JK, Severi G, English DR, Baglietto L, Krishnan K, Hopper JL, Giles GG. Body size, weight change, and risk of colon cancer. Cancer Epidemiol Biomarkers Prev. 2010;19(11):2978-86. doi:10.1158/1055-9965. EPI-10-0543

31. Win AK, Dowty JG, English DR, Campbell PT, Young JP, Winship I, et al. Body mass index in early adulthood and colorectal cancer risk for carriers and non-carriers of germline mutations in DNA mismatch repair genes. Br J Cancer. 2011;105(1):162-9. doi: $10.1038 /$ bjc. 2011.172

32. Siegel RL, Fedewa SA, Anderson WF Miller KD, Ma J, Rosenberg PS, Jemal A. Colorectal cancer incidence patterns in the 
United States, 1974-2013. J Natl Cancer Inst. 2017;109(8). doi:10.1093/jnci/djw322

33. Renehan AG, Zwahlen $M$, Egger $M$. Adiposity and cancer risk: New mechanistic insights from epidemiology. Nat Rev Cancer. 2015; doi: 10.1038/nrc3967

34. Giovannucci E. Metabolic syndrome, hyperinsulinemia, and colon cancer: a review. Am J Clin Nutr. 2007;86(3):836-42. doi: $10.1093 / \mathrm{ajcn} / 86.3 .836 \mathrm{~S}$

35. Mayer-Davis EJ, Lawrence JM, Dabelea D, Divers J, Isom S, Dolan L, et al. Incidence trends of type 1 and type 2 diabetes among youths, 2002-2012. New Engl J Med. 2017; 376(15):1419-29. doi:10.1056/NEJMc1706291

36. Al Obeed OA, Alkhayal KA, Al Sheikh A, Zubaidi AM, Vaali-Mohammed MA, Boushi, et al. Increased expression of tumor necrosis factor- $\alpha$ is associated with advanced colorectal cancer stages. World J Gastroenterol. 2014;20(48):18390-6. doi:10. 3748/wjg.v20.i48.18390

37. Joshi RK, Kim WJ, Lee SA. Association between obesity-related adipokines and colorectal cancer: a case-control study and meta-analysis. World J Gastroenterol. 2014;20(24):7941-9. doi:10.3748/wjg.v20. i24.7941

38. Waldner MJ, Foersch S, Neurath MF, Interleukin-6-a key regulator of colorectal cancer development. Int J Biol Sci. 2012;8(9):1248-53. doi:10.7150/ijbs.4614
39. Wei EK, Wolin KY, Colditz GA. Time course of risk factors in cancer etiology and progression. J Clin Oncol. 2010;28(26): 4052-7. doi:10.1200/JCO.2009.26.9324

40. Alfieri M, Pomerleau J, Grace DM. A comparison of fat intake of normal weight, moderately obese and severely obese subjects. Obes Surg. 1997;7(1):9-15. doi:10.1381/096089297765556150

41. Jeon KJ, Lee O, Kim HK, Han SN. Comparison of the dietary intake and clinical characteristics of obese and normal weight adults. Nutr Res Pract. 2011; 5(4):329-36. doi:10.4162/nrp.2011.5.4.329

42. Malinauskas BM, Raedeke TD, Aeby VG, Smith JL, Dallas MB. Dieting practices, weight perceptions, and body composition: a comparison of normal weight, overweight, and obese college females. Nutr J. 2006;5(1):11. doi:10.1186/1475-2891-5-11

43. Spencer EA, Appleby PN, Davey GK, Key TJ. Diet and body mass index in 38000 EPIC-Oxford meat-eaters, fish-eaters, vegetarians and vegans. Int $\mathrm{J}$ Obes Relat Metab Disord. 2003; 27(6):728-34. doi:10. 1038/sj.ijo.0802300

44. Vergnaud AC, Norat $T$, Mouw $T$, Romaguera D, May AM, Bueno-deMesquita $\mathrm{HB}$, et al. Macronutrient composition of the diet and prospective weight change in participants of the EPIC-PANACEA Study. PLoS ONE. 2013;8(3):e57300. doi:10.1371/journal.pone. 0057300

45. Bernstein AM, Song M, Zhang X, Pan A, Wang $M$, Fuchs CS, et al. Processed and unprocessed red meat and risk of colorectal cancer: analysis by tumor location and modification by time. PloS One. 2015;10(8):e0135959. doi:10.1371/journal. pone.0135959

46. Steinmetz KA, Potter J. Egg consumption and cancer of the colon and rectum. Eur J Cancer Prev. 1994;3:237-45. doi: 10.1097/ 00008469-199403030-00002

47. Vecchia CL, Franceschi S, Bidoli E, Barbone F, Dolara P. Refined-sugar intake and the risk of colorectal cancer in humans. Int J Cancer. 1993;55(3):386-9. doi:10.1002/ ijc. 2910550308

48. Chiavarini M, Bertarelli G, Minelli L, Fabiani R. Dietary intake of meat cooking-related mutagens (HCAs) and risk of colorectal adenoma and cancer: a systematic review and meta-analysis. Nutrients. 2017;9(5):514. doi:10.3390/nu9050514

Manuscript received on 19 April 2018. Accepted for publication on 6 August 2018.
RESUMEN

\section{Obesidad a edad temprana y riesgo de cáncer colorrectal en el adulto: metanálisis}

Objetivo. En este metanálisis se examina la relación entre la obesidad a edad temprana y el riesgo de cáncer colorrectal en la edad adulta.

Métodos. Se llevó a cabo una búsqueda sistemática en Google Scholar, PubMed y datos de referencia. Se seleccionaron 15 estudios pertinentes y se realizó un metanálisis de esos estudios (hombres y mujeres por separado). Se usó un modelo de efectos aleatorios para comparar los riesgos relativos (RR) ajustados por multivariantes de tener cáncer colorrectal en las categorías de personas con mayor y menor índice de masa corporal (IMC) a edad temprana. Se realizó una metarregresión de los factores que pueden haber contribuido con la heterogeneidad entre estudios.

Resultados. Un IMC alto a edad temprana está asociado con un aumento de 39\% del riesgo de cáncer colorrectal en los hombres adultos $(R R=1,39$, IC de 95\% 1,20 - 1,62, $P<0,0001)$ y un aumento de $19 \%$ del riesgo de cáncer colorrectal en las mujeres adultas $(\mathrm{RR}=1,19$, IC de 95\% 1,06 - 1,35, $P=0,004)$. En la metarregresión no se encontró una heterogeneidad estadísticamente significativa por subsitio tumoral $(R R=1,06$, IC de $95 \% 0,97-1,17, \mathrm{RR}=1,08$, IC de 95\% 0,99-1,18 para cáncer de colon proximal masculino y femenino; $R R=1,51$, IC de $95 \% 1,22-1,87$, RR = 1,08, IC de 95\% 0,98-1,19 para cáncer de colon distal masculino y femenino; y RR =1,39, IC de 95\% 1,1 - 1,77, $\mathrm{RR}=1,51$, IC de 95\% 0,94 - 2,03 para cáncer rectal masculino y femenino) u otros factores, incluidos edad de la evaluación del IMC, IMC notificado o medido por la propia persona y ajuste por tabaquismo.

Conclusiones. Los resultados indican que un IMC alto a edad temprana está asociado con un mayor riesgo de cáncer colorrectal en la edad adulta. Deben realizarse otros estudios para investigar el riesgo de cáncer colorrectal en el adulto en las personas obesas a edad temprana de países no occidentales, así como los mecanismos subyacentes por los cuales la adiposidad a edad temprana puede influir en la patogénesis del cáncer colorrectal.

Palabras clave
Neoplasias colorrectales; neoplasias del recto; obesidad; índice de masa corporal; metaanálisis. 
RESUMO Objetivo. Examinar a relação entre a obesidade no início da vida e o risco de câncer colorretal na vida adulta.

\section{Obesidade no início da vida e risco de câncer colorretal na vida adulta: uma meta- análise}

Métodos. Foi realizada uma busca sistemática nas bases de dados do Google Scholar e PubMed e em dados de referência. Quinze estudos relevantes foram identificados e foi realizada uma meta-análise em separado para homens e mulheres. Um modelo de efeitos aleatórios foi usado para comparar os riscos relativos (RR) ajustados para multivariáveis de câncer colorretal de modo geral e específico ao subsítio às faixas superiores e inferiores de índice de massa corporal (IMC) no início da vida. Foi realizada uma análise de metarregressão dos fatores que possivelmente contribuíram para a heterogeneidade entre os estudos.

Resultados. IMC alto no início da vida foi associado a um aumento de $39 \%$ no risco de câncer colorretal em homens adultos (RR 1,39, IC 95\% 1,20-1,62, $P<0,0001$ ) e um aumento de $19 \%$ no risco de câncer colorretal em mulheres adultas (RR 1,19, IC 95\% $1,06-1,35, P=0,004)$. Heterogeneidade estatisticamente não significativa foi identificada na análise de metarregressão segundo subsítio tumoral (RR 1,06, IC 95\% 0,971,17; RR 1,08, IC 95\% 0,99-1,18 para o câncer de cólon proximal no sexo masculino e no sexo feminino; RR 1,51, IC 95\% 1,22-1,87; RR 1,08, IC 95\% 0,98-1,19 para o câncer de cólon distal no sexo masculino e no sexo feminino; e RR 1,39, IC 95\% 1,1-1,77; RR 1,51, IC 95\% 0,94-2,03 para o câncer retal no sexo masculino e no sexo feminino) e outros fatores, como idade na avaliação do IMC, IMC autorrelatado ou medido e ajuste para tabagismo.

Conclusões. Os resultados do estudo indicam que um IMC alto no início da vida está associado ao aumento do risco de câncer colorretal na vida adulta. Outros estudos devem ser realizados para investigar o risco de câncer colorretal na vida adulta em indivíduos obesos no início da vida em países não ocidentais assim como pesquisar os mecanismos subjacentes pelos quais a adiposidade no início da vida pode influir na patogênese do câncer colorretal.

Palavras-chave Neoplasias colorretais; neoplasias retais; obesidade; índice de massa corporal; metanálise. 